\title{
Peningkatan Kadar Troponin-I Paska Resusitasi Cairan pada Sus Scrofa Sebagai Model Hewan Coba Renjatan
}

\author{
Hotber E.R Pasaribu ${ }^{1,2^{*}}$, Antonius H Pudjiadi ${ }^{3}$, Rismala Dewi ${ }^{3}$
}

\begin{abstract}
Provision large amounts of fluids in a short period is known can cause hypervolemia. Therefore, an examination is needed to find out that the fluid resuscitation being administered does not cause hypervolemia. The purpose of this study is to assess the effect of hypervolemic resuscitation on cardiac contractility. The study was conducted on 10 male Sus Scrofa aged 6-8 weeks, as shocked animal models. There are 3 types of resuscitation treatments : normovolemic, hypervolemic-1, and hypervolemic-2. Cardiac contractility was assessed using DPmax and troponin-i levels. There was an increase in troponin-i levels after hypervolemic fluid resuscitation $(\mathrm{p}=0.05)$. There is a decrease in cardiac contractility after hypervolemic resuscitation. Decreased cardiac contractility is associated with increased troponin-i ( $\mathrm{r}=0.720$; $\mathrm{p}=$ 0.020). Based on the results, we conclude hypervolemic resuscitation causes changes in troponin-i levels, which reflect changes in cardiac contractility.
\end{abstract}

Keyword: Hypervolemic, Dpmax, Troponin-i.

Renjatan merupakan suatu keadaan klinis yang sering dihadapi dalam penatalaksanaan pasien anak di UGD maupun di ruang rawat intensif anak. Pada renjatan terjadi gangguan keseimbangan antara konsumsi dengan pasokan oksigen di jaringan. Pasokan oksigen di jaringan dapat ditingkatkan melalui resusitasi cairan. ${ }^{1,2}$

Early goal direct therapy (EGDT) yang di populerkan oleh Rivers dkk ${ }^{3}$, telah digunakan secara luas sebagai standar dalam penatalaksanaan resusitasi cairan pasien renjatan sepsis. Protokol EGDT ini merekomendasikan pemberian sejumlah besar cairan kristaloid atau koloid secara bolus, hingga target perfusi membaik, atau dihentikan bila teraba pembesaran hati dan timbul ronki basah. ${ }^{4-6}$ Pada pelaksanaannya resusitasi cairan secara bolus dapat menimbulkan komplikasi hipervolemik cairan didalam tubuh.

\footnotetext{
* Penulis untuk korespondensi : hotberpasaribu27@gmail.com

1 KJF Ilmu Kesehatan Anak, Fakultas Kedokteran Universitas Riau

2 Program Studi Sp2 Ilmu Kesehatan Anak, Fakultas Kedokteran Universitas Indonesia

3 Departemen Ilmu Kesehatan Anak, Fakultas Kedokteran Universitas Indonesia
}

Hipervolemik akibat resusitasi cairan secara bolus dapat meningkatkan angka mortalitas sampai dengan 10,7\%. Hal ini telah diamati oleh Maitland $\mathrm{dkk}^{5}$ melalui suatu penelitian dengan subjek anak yang mengalami renjatan malaria di Sahara, Afrika. Pada pengamatan Maitland dkk, resusitasi cairan secara bolus angka mortalitasnya meningkat lebih tinggi dibandingkan dengan resusitasi cairan secara lambat yaitu 7,3\% $(\mathrm{p}<0,05) .^{5}$

Jantung merupakan salah satu organ yang dapat mengalami dampak akibat hipervolemik cairan. Keadaan hipervolemik ini dapat menyebabkan peregangan pada dinding ventrikel kiri jantung. Peregangan dinding ventrikel kiri jantung yang berlebihan dapat menyebabkan gangguan utilisasi oksigen, menurunnya difusi produk metabolisme seluler dan kerusakan sel miosit sehingga terjadi kegagalan organ jantung progresif. ${ }^{7,8}$

Kerusakan miosit dapat diketahui melalui pemeriksaan kadar troponin yang terdeteksi di dalam darah. Troponin merupakan kompleks protein filamen aktin pada sel miosit jantung yang berperan dalam kontraksi otot jantung bersama kalsium, miosin dan tropomiosin. Troponin yang spesifik terhadap sel miosit jantung adalah troponin-i. Kadar 
troponin-i di dalam darah dapat dipakai sebagai marker infark jantung dengan nilai diskriminasi ROC sebesar 94 \%. Selama ini Troponin-i telah banyak digunakan di bagian kardiologi dewasa untuk menentukan tingkat kerusakan sel miosit akibat infark miokard. Semakin luas infark miokard maka akan semakin tinggi pula kadar troponin-i di dalam darah. ${ }^{9,10}$

Pada beberapa penelitian telah diketahui kadar troponin-i juga meningkat meskipun tidak terbukti adanya infark miokard. Mekanisme peningkatan troponin-i non infark miokard ini diperkirakan melalui jalur iskemik atau jalur reperfusi sel miosit jantung. Pada keadaan ini membran sel menjadi mudah dilewati oleh troponin-i yang sebelumnya telah berada di dalam sitosol miosit dalam bentuk bebas. Troponin-i yang keluar dari sitosol ini akan masuk ke dalam darah dan dapat dideteksi kadarnya melalui pemeriksaan secara invitro menggunakan alat iStat dari abboot. ${ }^{11}$

Jika troponin-i meningkat di dalam darah berarti telah terjadi penurunan troponin-i di dalam sitosol. Karena troponin-i berperan dalam pembentukan kontraksi jantung maka pada setiap penurunan troponin-i di dalam sitosol dapat menyebabkan menurunnya kontraktilitas jantung. Peranan troponin-i dalam membentuk kontraktilitas adalah melalui pergeseran filamen (sliding filament model) dan mekanisme jembatan silang (cross bridge hypotesis). Komplek troponin-i bersama kalsium menyebabkan perubahan permeabilitas permukaan miosin sehingga terjadi pemendekan sarkomer. ${ }^{12-14}$ Selain itu, terdapat parameter Maximal Intraventricular Developed Pressure (DPmax) pada alat PiCCO yang dapat dijadikan sebagai indikator hemodinamik. Parameter DPmax ini dapat melakukan penilaian kemampuan kontraksi jantung berdasarkan besar tekanan yang ditimbulkan pada saat kontraksi. ${ }^{15}$ Berdasarkan latar belakang tersebut, adapun tujuan penelitian ini adalah untuk mengetahui pengaruh hipervolemik terhadap kontraktilitas jantung dengan mengamati perubahan kadar troponin-i dan DPmax.

\section{METODE}

Penelitian ini merupakan penelitian dengan desain pre and post intervention pada hewan coba Sus Scrofa sebagai model hewan renjatan. Penelitian dilaksanakan di laboratorium Rumah Sakit Hewan/ Fakultas Kedokteran Hewan IPB Bogor pada 8 18 Juni 2017. Sampel penelitian ini berjumlah 10 ekor babi (ditentukan berdasarkan rumus Federer). Kriteria inklusi yang ditetapkan yaitu babi jantan berusia 6 - 8 minggu dengan berat badan 12 - 15 kg. Sedangkan kriteria eksklusinya adalah babi yang mengalami sakit selama proses penelitian. Variabel terikat dalam penelitian ini adalah DPmax dan Troponin-i.

Pembuatan model renjatan dilakukan dengan metode fixed pressure hemorrhage ${ }^{16}$ (induksi renjatan dengan mengeluarkan darah hingga terjadi penurunan MAP sebesar 20\% dari MAP baseline), kemudian sampel diberikan resusitasi cairan. Resusitasi pertama dilakukan dengan pemberian cairan sesuai darah yang dikeluarkan (resusitasi normovolemik), dilanjutkan dengan pemberian cairan sejumlah $40 \mathrm{ml} / \mathrm{kg}$ (resusitasi hipervolemik-1) dan kemudian diberikan cairan kembali sebesar $40 \mathrm{ml} /$ kg (resusitasi hipervolemik-2). Kontraktilitas jantung diukur menggunakan parameter DPmax pada PiCCO dan kadar troponin-i menggunakan alat iStat dari Abbott. Pengukuran data dilakukan pada tahap awal sebelum perlakuan, sesaat setelah renjatan, dan pada setiap fase resusitasi. Data yang didapat diolah menggunakan program SPSS versi 20.0 ; dengan nilai signifikansi $\mathrm{p}<0,05$ dinyatakan signifikan.

\section{HASIL}

Total 10 sampel yang diikut sertakan dalam penelitian ini. Menurut dokter hewan yang merawat, keseluruhan Sus Scrofa sebelum pelaksanaan penelitian dalam keadaan sehat. Adapun karakteristik sampel pada penelitian ini disajikan pada tabel 1 . 
Tabel 1. Karakteristik Dasar Model Sus Scrofa $(\mathrm{n}=10)$

\begin{tabular}{lc}
\hline & Rerata \pm SB \\
\hline Berat anak babi $(\mathrm{kg})$ & $14,4 \pm 1,2$ \\
Luas permukaan tubuh $\left(\mathrm{m}^{2}\right)$ & $0,47 \pm 0,02$ \\
MAP (mmHg) & $103 \pm 14,7$ \\
Troponin $(\mathrm{ng} / \mathrm{ml})$ & $0,1 \pm 0,04$ \\
Cairan input normovolemik & $90(45-140)^{*}$ \\
Cairan input hipervolemik-1** & $576 \pm 40$ \\
Cairan input hipervolemik-2** & $1152 \pm 80$ \\
\hline
\end{tabular}

Keterangan : SB, simpang baku; *Nilai tengah (minimal - maksimal), MAP, mean arterial pressure. ${ }^{* *}$ Cairan input hipervolemik-1 $=40 \mathrm{ml} / \mathrm{kgbb}, * * *$ Cairan input hipervolemik- $2=80 \mathrm{ml} / \mathrm{kgbb}$

Hasil pengukuran troponin i pada saat sebelum induksi perlakuan, setelah renjatan, dan pada setiap fase resusitasi diperlihatkan pada gambar 2 . Didapatkan nilai tengah troponin-i pada renjatan mengalami kenaikan yang sangat besar jika dibandingkan baseline dengan kemiringan kurva positif yang sangat curam. Kenaikan nilai troponin$i$ masih terus berlanjut pada normovolemik namun kemiringan kurva sudah mulai landai. Sebaliknya pada hipervolemik-1 nilai troponin-i justru mengalami penurunan dengan kemiringan kurva negatif yang landai kebawah. Selanjutnya pada hipervolemik-2 kemiringan kurva kembali positif dengan kemiringan kurva yang melandai ke atas. Dari hasil uji statistik menggunakan uji wilcoxon didapatkan pada hipervolemik-1 nilai troponin-i mengalami penurunan yang bermakna $(p=0,010)$ dibandingkan normovolemik. Sebaliknya pada hipervolemik-2 justru kadar troponin-i mengalami kenaikan yang bermakna $(\mathrm{p}=0,007)$ dibandingkan normovolemik.

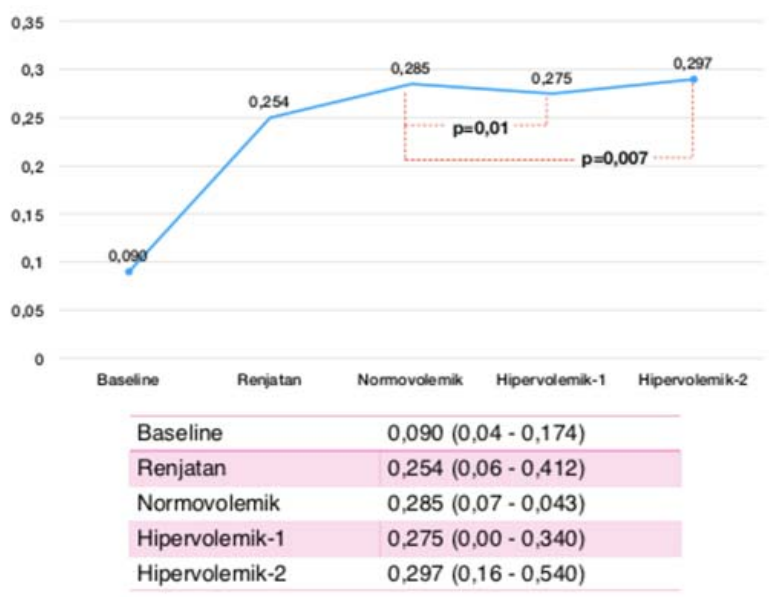

Gambar 2. Perubahan kadar troponin-i
Perubahan nilai DPmax ditampilkan pada Gambar 3. Didapatkan nilai rerata DPmax mengalami peningkatan dari $628 \pm 186 \mathrm{mmHg} / \mathrm{s}$ pada normovolemik menjadi $659 \pm 195 \mathrm{mmHg} / \mathrm{s}$ pada hipervolemik-1. Selanjutnya dilakukan uji tberpasangan dengan hasil $p=0,493$. Perbedaan mean DPmax ini adalah sebesar $339 \mathrm{mmHg} / \mathrm{s}$ (95\% IK $330-408 \mathrm{mmHg} / \mathrm{s})$ dengan korelasi lemah $(\mathrm{r}=$ 0,246). Pada hipervolemik-2 terdapat penurunan DPmax yang bermakna dari $628 \pm 186 \mathrm{mmHg} / \mathrm{s}$ pada normovolemik menjadi $640 \pm 142 \mathrm{mmHg} / \mathrm{s}$ pada hipervolemik-2 $(\mathrm{p}=0,01)$. Perbedaan mean DPmax ini adalah sebesar $134 \mathrm{mmHg} / \mathrm{s}$ (IK95\% 58-327 $\mathrm{mmHg} / \mathrm{s}$ ) dengan korelasi kuat yaitu sebesar 0,762.

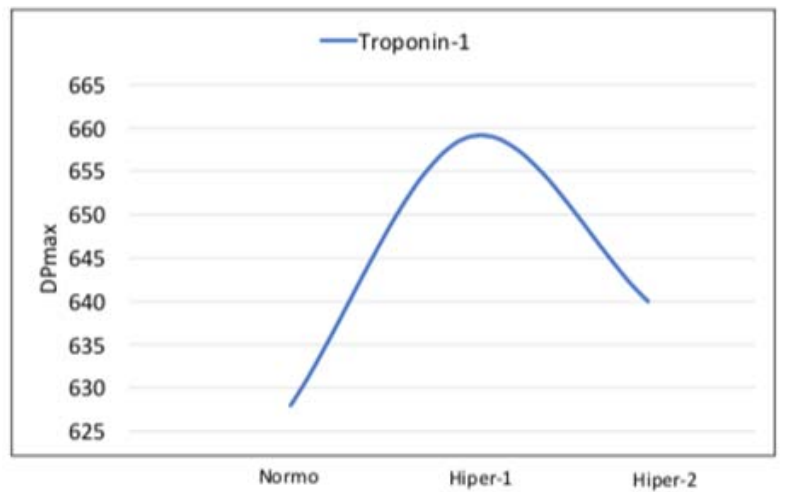

Gambar 3. Perubahan nilai DP max terhadap troponin-i

\section{PEMBAHASAN}

Status hipervolemik dalam penelitian ini menggunakan rumus Houseman. ${ }^{17}$ Berdasarkan formula Houseman, keseluruhan hewan coba telah mengalami akumulasi cairan tubuh sebanyak 6,6 \% pada hipervolemik-1 dan 14\% pada hipervolemik-2. 
Akumulasi cairan sebanyak ini jika terjadi pada manusia tentu saja sudah menyebabkan hipervolemik. Menurut Trof dkk, ${ }^{18}$ akumulasi cairan yang melebihi $10 \mathrm{ml} / \mathrm{kgbb}$ telah menyebabkan peningkatan extra vascular lung water (EVLW). Masih berkaitan dengan hal tersebut, La Combe $\mathrm{dkk},{ }^{19}$ dalam makalah yang berjudul hubungan antara fisiologi kardiovaskular dan hukum starling mengatakan bahwa penambahan cairan di dalam intravaskular akan meningkatkan volume darah pada ventrikel kiri jantung. Berdasarkan perhitungan dan landasan teori di atas dapat disimpulkan target hipervolemik dan peningkatan volume ventrikel kiri pada penelitian ini telah tercapai.

Kenaikan troponin-i yang dihubungkan dengan waktu sebaiknya dilakukan sebagai primary study sebelum dilakukan penelitian lebih lanjut pada manusia. Hal ini belum dilakukan, karena penelitian ini merupakan suatu bagian dari payung penelitian yang masih berjalan. Seharusnya pemeriksaan troponin-i dapat dilakukan secara serial setiap 10 menit pada setiap sesi intervensi. Jika hal ini dilakukan nantinya akan diketahui pola kenaikan troponin-i tersebut pada setiap perubahan waktu. Hal ini penting karena pada kenyataan klinis seharihari keadaan renjatan dan resusitasi cairan berlangsung sangat cepat. Sehingga perlu pembuktian bahwa troponin-i tersebut memang bisa terdeteksi pada keadaan klinis yang singkat.

Pada hipervolemik-1 tampak kadar troponin-i mengalami penurunan dibandingkan normovolemik. Perlu dibuktikan bahwa penurunan troponin-i pada fase ini adalah murni akibat peregangan dinding ventrikel kiri jantung dan bukan karena faktor hemodilusi. Hal tersebut dapat diketahui dengan melihat perubahan pada perbandingan kadar troponin-i dengan albumin. Perbandingan perubahan albumin-troponin ini dapat menghilangkan faktor hemodilusi akibat penambahan cairan pada resusitasi. Hal yang sama dilakukan oleh Castro $\mathrm{dkk},{ }^{20}$ tentang faktor hemodinamik dan oksigenasi jaringan setelah pemberian cairan dengan melihat perbandingan rasio dextrans dan albumin. Pemeriksaan albumin tidak dilakukan dalam penelitian ini karena bukan merupakan bagian dari tujuan penelitian.

Penurunan troponin-i pada hipervolemik-1 disebabkan keseluruhan hewan coba masih dalam fase normovolemik. Panjang otot ventrikel kiri jantung belum melampaui Lmax dengan panjang miosit yang optimal. Keadaan hipervolemik yang sebenarnya baru tercapai pada hipervolemik-2 dengan jumlah akumulasi cairan sebesar 14\%. Hal ini sama dengan hasil penelitian Pudjiadi dkk, ${ }^{16}$ yang menyebutkan resusitasi dengan pemberian cairan lebih dari $10 \mathrm{ml} /$ KgBB dapat mengakibatkan peningkatan extra vascular lung water index (ELWI). Pudjiadi $\mathrm{dkk}^{16}$ juga melaporkan pemberian cairan secara bolus tidak meningkatkan atrial natriuretik peptide (ANP) sampai merusak glikokaliks. Hal ini terjadi karena ada faktor perikardium yang berperan dalam mempertahankan kadar ANP tidak naik. Sedangkan menurut Kirov dkk ${ }^{21}$, bahwa pada fase hipervolemik akan tampak perubahan homeostasis sistem kardiovaskular melalui parameter ELWI.

Pada penelitian ini kemungkinan troponin-i yang terdeteksi berasal dari troponin-i bebas di sitosol. Hal ini terbukti pada hipervolemik-1 justru kadar troponin-i mengalami penurunan dibandingkan sebelumnya pada normovolemik. Peningkatan kadar troponin-i pada normovolemik kemungkinan masih merupakan lanjutan dari keadaan hipoksia yang terjadi pada fase renjatan. Pada hipervolemik-1 diperkirakan volume yang ditambahkan justru membuat sarkomer mencapai panjang optimal. Panjang optimal sarkomer menyebabkan permeabilitas membran kembali membaik. Pada hipervolemik-2 penambahan volume menyebabkan peregangan sarkomer melampaui $\mathrm{L}_{\max }$. Peregangan melampaui $\mathrm{L}_{\max }$ akan diikuti dengan peregangan membran sel sehingga memudahkan troponin- $i$ keluar dari sitosol. ${ }^{22}$

Kontraktilitas jantung merupakan salah satu faktor yang menentukan CO. Kontraktilitas jantung adalah representasi kekuatan otot jantung yang independen terhadap preload dan afterload. Peningkatan kemampuan kontraksi jantung, eksklusif bergantung pada substansi ion kalsium pada intraseluler. Perbedaan konsentrasi ion kalsium intraseluler menyebabkan perbedaan derajat ikatan ion kalsium dengan filamen aktin dan miosin pada otot jantung. ${ }^{23}$

Berdasarkan penelitian yang dilakukan oleh

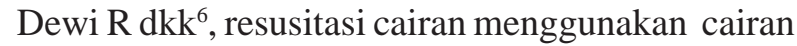
kristaloid dapat menyebabkan EVLW lebih tinggi dibandingkan dengan menggunakan cairan koloid. 
Peningkatan volume di dalam kapiler paru akan menyebabkan tekanan di dalam kapiler paru juga meningkat. Apabila tekanan yang dihasilkan mencapai besar tekanan yang sama dengan tekanan osmotik koloid maka pada saat yang bersamaan cairan akan merembes ke ekstra kapiler. Cairan tersebut akan masuk ke ruang interstisiel paru dan alveoli dan menyebabkan edema paru yang ditandai dengan peningkatan EVLW. ${ }^{24}$

Pada penelitian ini hipervolemik teramati menimbulkan peregangan otot jantung. Karena volume pada hipervolemik ini menyebabkan peningkatan LVEDV. Seperti yang telah disebutkan sebelumnya oleh La Combe dkk, ${ }^{18}$ bahwa penambahan cairan di dalam intravaskular akan meningkatkan volume darah pada ventrikel kiri jantung. LVEDV yang berlebih akan menyebabkan kemampuan kontraksi jantung berkurang.

Diperkirakan pada resusitasi cairan yang pertama dengan memasukkan cairan $40 \mathrm{ml} / \mathrm{kg}$ belum terjadi penurunan kontraktilitas jantung karena LVEDV baru mencapai $\mathrm{L}_{\max }$. Pada fase ini justru persentase peregangan otot baru mencapai 100 persen, hal ini dibuktikan dengan adanya peningkatan DPmax. Seperti pengamatan oleh Keurs dkk ${ }^{22}$, pada panjang sarcomer $\mathrm{L}_{\max }$ yang optimal akan menyebabkan perubahan energi peregangan isometrik menjadi kontraksi isotonik. Penurunan DPmax terdapat pada hipervolemia-2. Korelasi negatif pada hipervolemia-2 terjadi karena peningkatan volume cairan intravaskular cenderung meningkatkan aliran balik vena jantung, selanjutnya akan menyebabkan peningkatan tekanan pada LV.

Feng dkk ${ }^{25}$ melaporkan peningkatan troponin$i$ teramati pada penderita dengan peningkatan preload secara bermakna meskipun tidak terbukti mengalami iskemik jantung. Penelitian invivo pada miosit LV yang diberikan protein kinase Cß2 yang dilakukan oleh Takeishi $\mathrm{dkk},{ }^{26}$ menyebutkan terdapat peningkatan kadar troponin-i pada miosit tikus yang diberikan protein kinase Cß2. Peningkatan troponin$i$ berkorelasi dengan penurunan respon kalsium myofibril dan kontraktilitas jantung. Telah diketahui juga sebelumnya bahwa pada jantung sehat kadar protein kinase Cß2 akan meningkat dan terdeteksi apabila organ ini mengalami gangguan fungsi kontraksi akibat peregangan dinding dan penurunan fungsi miosit. ${ }^{21}$

\section{KESIMPULAN}

Pada hewan model dengan cairan hipervolemik, hipervolemik berhubungan dengan peningkatan kadar troponin-i, dan peningkatan troponin-i berkorelasi dengan penurunan kontraktilitas jantung.

\section{SARAN}

Dibutuhkan penelitian lebih lanjut pada subjek manusia terhadap kadar troponin-i sebagai indikator penurunan kontraktilitas jantung pada resusitasi cairan. Selain itu juga perlu dilakukannya penelitian untuk mengetahui dinamika kenaikan troponin-i berdasarkan perubahan waktu.

\section{DAFTAR PUSTAKA}

1. Boldt J, Ince C. The impact of fluid therapy on microcirculation and tissue oxygenation in hypovolemic patients: a review. Intens Care Med. 2010;36:1299-308.

2. Somasetia DH, Sjahrodji AM, Idjradinata PS, Setiabudi S, Roth H, Ichai C, dkk. Early resuscitation of dengue shock syndrome in chidlren with hyperosmolar sodium-lactate: A randomized single-blind clinical trial of efficacy and safety. Crit Care Med. 2014;18:1-11.

3. Rivers E, Nguyen B, Havstad S, Ressler J, Muzzin A, Knoblich B, dkk. Early goal-directed therapy in the treatment of severe sepsis and septic shock. N Engl J Med. 2001;345:1368-72.

4. Rhodes A, Evans LE, Alhazzani W. Surviving sepsis campaign: International guidelines for management of sepsis and septic shock: Intensive Care Med. 2017;43:304-77.

5. Maitland K, Kiguli S, Opoka RO, Engoru C, Olupot-olupot P, Akesh SO, dkk. Mortality after fluid bolus in African children with severe infection. N Eng J Med. 2011;364: 2483-95.

6. Dewi R, Supriyatno B Madjid AS. The effects of colloid or crystalloids on acute respiratory syndrome in swine (Sus Suscrofa) models with severe sepsis:analysis on extravascular lung water, IL-8, and VCAM-1. Med J Ind. 2016;25:33-8. 
7. Sanada S, Komuro I, Kitakaze M. Pathophysiology of myocardial reperfusion injury: Preconditioning, postconditioning and translational aspects of protective measure. Am J Phys Heart and Circ Phys Pub. 2011;301:1723-41.

8. Cannon Ro. Mechanisms, management and future directions for reperfusion injury after acute myocardial infarction. Nat Clin Pract Cardiovasc Med. 2005;2:88-90.

9. Ebashi S, Ohtsuki I. Troponin : structure, function and dysfunction. Adv Exp Med Biol. 2000;592:2139.

10.Fernandes CJ Jr, Akamine N, and Knobel E. Cardiac troponin: A new serum marker of myocardial injury in sepsis. Intensive Care Med. 1999;15:1165-8.

11. Freud Y, Chenevier-Gobeaux C, Bonnet P, Slaessens YE, dkk. High sensitivity versus conventional troponin in the emergency departement for the diagnosis of ecut myocardial infarction. Crit Care. 2011;15:1-9.

12. Apple FS, Wu AHB, Jaffe AS. Implementation of the ESC/ACC guidelines for redefenition of myocardial infarction using cardiac troponin assays with special attention to clinical trial issues. Am Hearth J. 2002;144:981-6.

13. Babuin L, Jaffe AS. Troponin: The biomarker of choice for the detection of cardiac injury. CMAJ. 2005;10:1191-202.

14. Tanindi A, Cemri M. Troponin elevation in condition other than acute coronary syndrome. Vasc Health Risk Manag. 2011;7:597-603.

15. Morimont P, Lambermont B, Desaive T, Janssen $\mathrm{N}$, Chase G, D'Orio V. Arterial dP/dtmax accurately reflects left ventricular contractility during shock when adequate vascular filling is achieved. BMC Cardiovasc Disord. 2012 Mar 1;12:13.

16.Pudjiadi AH. Pengaruh resusitasi normo dan hipervolemik terhadap hemodinamik Sus Scrofa sebagai model hewan coba renjatan: Kajian pada atrial natriuretic peptide, glycocalyx endotel vascular, extravascular lung water index, mean arterial pressure, kadar hemoglobin dan pasokan oksigen (Disertasi). Program Pendidikan Doktor
Ilmu Kedokteran. Jakarta: Universitas Indonesia, 2018.

17.Houseman RA, Mc Donald, Pennie K. The measurement of total body water ini living pigs by deuterium oxide dilution and its relation to body composition. Br J Nutr. 1973;30:149 - 56.

18. Trof RJ, Beishuizen A, Comet AD, De Wit RJ, Girbes ARJ, Groeneveld J. Volume-limited versus pressure limited hemodynamic management in septic and nonseptic shock. Crit Care Med. 2012;40:1177-85.

19.La Combe P, Lappin S. Physiology, cardiovascular, starling relationships. N Lib Med. 2017;6:1-4.

20.Castro C, Ortiz D, Palmer AF, Cabrales P. Hemodynamics and tissue oxygenation after hemodilution with ultrahigh molecuar weight polymerized albumin. Min Anest. 2014;80:53746.

21.Kirov MY, Kuzkov VV, Bjertnaes LJ. Extravascular lung water in sepsis. Crit Care Med. 2006;34:449-60.

22. Keurs HEDJT, Iwazumi T dan Pollack GH. The sarcomer length-tension relation in skletal muscle. J Gen Physiol. 1978;72:565-92.

23. Neves JS, Leite Moreira AM, Neiva SM, Almeida CJ. Acute myocardial response to stretch:what we don’t know. Frontier in Physiology. 2016;6:111.

24. Bougle A, Harrois A, Duranteau J. Resuscitative strategies in traumatic hemorrhagic shock. Ann Intensive Care. 2013;3:1-9.

25. Tomec RJ, Sun D, Carville DGM, Walsh MM. A rapid and sensitive assay for the evaluation of cardiac troponin-i (cTnI) using the $\mathrm{i}=\mathrm{STAT}$ bedside system. Memorial Hospital \& Health System, South Bend, IND and Clinical Solution \& Innovation, South Bend Indiana. 1989.

26. Takeishi Y, Chu G, Kirk Patrick, Li Z, Wakasaki $\mathrm{H}$, Kranias EG, dkk. In vivo phosphorylation of cardiac troponin-i by protein kinase Cß2 decreases cardiomyocyte calcium responsiveness and contractility in transgenic mouse hearts. J Clin Invest. 1998;102:72-8. 